\title{
PRAGMATISM AMONG BELIEVERS: MYTH OR REALITY?
}

\author{
SOFIYA HRABOVSKA soniah@ua.fm \\ Ivan Franko Lviv National University, Ukraine \\ MARYANA YESYP yankayesyp@gmail.com \\ van Franko Lviv National University, Ukraine
}

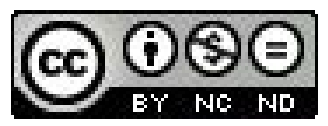

\begin{abstract}
This article reveals dependence between sense and life orientation and religious beliefs of believers. It is established that the tendency to understand God as a merciful and doting mentor is related to the aspirations to order one's life according not only to spiritual and moral values but also to pragmatic and egoistic values which help preserve one's individuality, contribute to financial growth and solving personal problems. Domination of negative ideas about God are accompanied by the indifferent attitude of a person to the issue of sense and life orientations.
\end{abstract}

Key words: pragmatic and egoistic values, spiritual and moral values, religious beliefs/ perceptions, believers.

Creation of the world of your life, its updating following the laws of truth, goodness and justice constitute important tasks faced by modern humans. For the person to realize and be able to implement the "project" of his individual being, he has to realize the sources of his mental life, to make an insight into the depth of the religious being. Considering his own system of views the person determines what will make a guideline in his life and what values he will follow in the future. Important values in Christian religion are disinterestedness, mercy, modesty, love and care for the people near and dear to you. However, the question arises whether pragmatic values aimed at getting personal benefit in some specific situations motivate the activity of believers. A detailed study of the problem remains, however, unattended by our domestic psychologists, in spite of the fact that, according to the data of the survey held by the International Social Studies Project, Ukrainians are one of the most religious nations in the Euro-Asian continent ${ }^{11}$.

While gaining individual experience the person who acknowledges existence of the supranatural world forms his religious beliefs. Typically, in psychology ideas are treated as an integrity of images of certain phenomena or objects available in human life (Contemporary psychological vocabulary 2000, p. 376-377). Religious beliefs are specific in that it is those images that reflect subjective understanding of transcendent reality (Wulff 1999, p. 557).

So, cognition of the supranatural world takes place due to the participation of an individual in the life of the religious community, reading of religious books,

11 http://www.razumkov.org.ua/upload/prz_2011_Rlg_smll.pdf 
reflections on religious matters, etc. On the basis of this the person forms a system of ideas on how he should act in some situations, for instance, the church points to the need to love and have respect for your neighbours under all circumstances, without bringing harm to your life and the life of people around you, etc. Besides that, under the influence of "meeting" supranatural reality individuals are preoccupied with various worries relating to God, they feel responsible for their own conduct. Religious ideas also appear due to communication of humans with God. Addressing God via prayer, they express their requests or gratitude for something, tell about their worries and hopes.

Religious beliefs are represented by different images, for instance, those of Christ, the Holy Virgin, apostles and other supranatural forces. The central place in the system is occupied by beliefs about God. That is a cognitive and emotional construct relating to understanding of the supranatural world and of himself by a human being. It is formed in the course of interaction of the individual with the environment as a system of meanings and sense with which the individual associates God.

Ideas about God are closely related to the system of beliefs of the religious. For some, God is a "moral authority", whose virtues should be followed in one's life; for others He is the leader who will provide support in a complicated situation (Pargament, Brant 1998, p. 111-129). Humans also resort to God due to the wish to reduce emotional tension caused by sinful actions, the fear of death as well as the desire to communicate through prayers and to be related to Him, etc. Thus, for believers God may by Himself be a value, an embodiment of Christian virtues as well as a means through which they will achieve the desirable, for instance, will ensure a certain status in society for themselves (Allport 1998, p. 225).

For a person who accepts his religious beliefs, addresses them in his everyday life, and devotes much time to religious practices, God becomes a good leader taking care of his life. The man stresses in His image the Divine magnitude and holiness, unrestricted power and unconditional love. Confirmation of the connection of inner religious orientation with the image of a benevolent God can be found in the studies by Gordon W. Allport, Ana Wong-McDonald, Richard L. Gorsuch and Charles A. Schaefer (Allport 1998, p. 225). Scholars have shown that as far as people who consider God to be the source of unrestricted love and constant support in hard moments of life are concerned, religious beliefs determine their life philosophy. Unlike them, believers who are prone to construct the image of a ruthless and gloomy God, use religion to achieve their personal goals which are rarely related to their spiritual development and enrichment. Such believers resort to religious practices only because it is accepted to do so in their surroundings, they do not do it on their own initiative.

On the basis of the above one can assume that religious ideas constitute a regulator of our conduct, due to which an individual directs his activity into the corresponding area, and forms his own life philosophy. A believer, for whom God is an embodiment of love and benevolence, aspires to make altruistic actions, in particular, he provides spiritual and social support to others (Maynard, Gorsuch, Bjorck 2001, p. 65-79). The activity of such person is motivated by spiritual and moral values reflecting the individual's attitude to the surrounding world. According to 
the study of Christian communities, respect for and love to neighbours, restraint, justice, etc., come to be the guidelines in human conscience. These are the values helping believers to self-actualize in the spiritual and moral spheres. However, in the epoch of social and economic life intensification man acts as a consumer of certain goods, he strives to get benefits from his activity and to show his own achievements to his neighbours. Hence, the issue of what values - spiritual and moral or pragmatic and egoistic - motivate the activity of believers depending on their idea about God needs to undergo an empirical study.

\section{RESEARCH PROCEDURE}

With this in view, 320 people (aged 18-35) identifying themselves as believers have been surveyed. Out of them $50 \%$ are women and $50 \%$ are men. Since according to the data of the Razumkov Centre's study, the highest level of piety can be traced among the residents of the western regions of Ukraine (89\% people) ${ }^{12}$, representatives of Halychyna area were taken for the survey.

To study the dependence of spiritual and moral and pragmatic and egoistic values on religious beliefs of man a number of empirical criteria have been used. The perception of God studied using the methodology The Image of God with the Religious (by Maryana Yesyp) (Esip 2010, p. 29-38) constitutes a marker of religious beliefs. Using this methodology one can analyze the following perceptions of God: God as a benefactor, as a tyrant, as an Absolute, a care-taker, a judge, a master of life and transcendence as well as a determiner of the integral factors - a positive and negative perception of God.

A positive perception of God lies in that God, in human opinion, is benevolent, caring, doting and merciful. He acts as an embodiment of excellence, holiness, mightiness and smartness for man. Being the master of the whole world, God takes care of the life of man, can console him in hard moments of life, evoking the feeling of safety and comfort with him. God, in the opinion of such person, forgives his sins and constantly points out the necessary direction to him. God in human imagination is often similar to his parents or some close relatives. He takes an important place in his life, attracts with His grandeur and excellence.

A negative perception of God is based on ascribing such characteristics as ruthlessness, aggressiveness and despotism to him. Such a God, in human opinion, ruthlessly takes revenge, punishes on an unfair basis and convicts for sinful actions. Hence, he becomes distant and unapproachable and in the human mind, it is complicated to address Him about one's requests. Man is of the opinion that God hates him, damages his life. In human opinion, God frequently prohibits him to do something and restricts his will.

Pragmatic and egoistic as well as spiritual and moral values of a believer constitute a marker of sense and life orientations. Those values were studied via Sopov's and Karpushyn's morphological test of life values. The methodology includes such spiritual and moral values as self-development, spiritual satisfaction, creativity and active social contacts. Out of pragmatic and egoistic ones the authors of the

12 http://www.razumkov.org.ua/upload/prz_2011_Rlg_smll.pdf 
methodology suggested the values of personal prestige, high financial standing, personal achievements and preserving one's individuality. The marker of sense and life orientations has also been set out in detail on the basis of the results of Everett Shostrom's test for the measurement of self-actualization as modified by Leonid Ya. Gozman and Mikhail V. Kroz. In particular, the scale The values of selfactualized personality has been used.

To process the data received we have used quantity methods of mathematical and statistical analysis (computer package STATISTICA in version 8.0). In particular, these were the methods of descriptive statistics, cluster analysis (following the algorithm of k-means according to the studies), comparative analysis following Student's t-criterion, unifactor dispersion analysis (variations analysis and Henry Scheffe's test).

\section{VALUE ORIENTATIONS OF BELIEVERS WITH DIFFERENT RELIGIOUS BELIEFS}

After the division of those surveyed by the factor of religious beliefs, it was traced that for an overwhelming majority of the believers surveyed $(85.2 \%)$ it is easy to determine how they imagine God. In particular, each second respondent has a positive perception of God (48.5\% of those surveyed) (Fig. 1).

Fig. 1. Imagine God (in percentage)

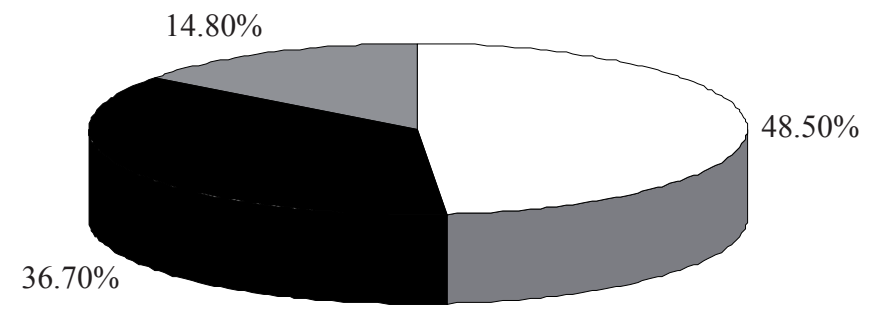

$\square$ People with a positive perception of God

- People with a negative perception of God

$\square$ People who have not yet got a clear perception about God

Source: Author.

Each third believer surveyed ( $36.7 \%$ of those surveyed) is prone to stress the negative characteristics of God (Fig. 1). However, there are respondents, of whom there is obviously a minority ( $14.8 \%$ of those surveyed) for whom it is difficult to determine how they see God. They are not sure whether God is an embodiment of love, mercy and mightiness or, maybe, despotism, injustice and indifference to their problems. Such believers have got vague religious beliefs deprived of clarity. Let us indicate that in case of further data processing it was the results of the first two groups of those surveyed that were taken into account since the number of people included there is relatively comparable. 
On the basis of the results obtained it has been traced that people who are prone to construct the image of merciful and all-mighty God more often follow their views in their lives and are guided by the values they have chosen independently, unlike those who consider God to be indifferent and unjust. This is confirmed by the results of a unifactor dispersion analysis (variations analysis and H. Scheffe's test): people characterized by a positive perception of God show higher statistically significant points by the scale The values of self-actualized personality, where $\mathrm{M}=11.767, \mathrm{~F}=3.215, \mathrm{p}=0.014$, unlike those surveyed with the negative type of the image of God, where $M=9.767$.

Believers for whom God is an embodiment of excellence, holiness, mightiness and smartness, show confidence in their views, trust their own assessment more frequently than others do. They consider themselves to be quite strong to act the way they want to, however, protecting their own interests, they do not forget about the feelings and wishes of others. Perception of God as a doting and merciful mentor inspires believers to prefer the values of self-actualized personality, in particular, those of the truth, goodness, integrity and self-sufficiency.

Orientation of humans at such values can testify to the high level of development of their spirituality and morality. And the following has been clarified in the further research. Believers who consider God to be mighty and benevolent aspire not only to achieve a higher level of evolution and development of their personality, but are also guided by the values of pragmatic and egoistic nature that motivate humans in their activity towards achievement of those values that bring some benefit to them.

We find a confirmation to that in the results of a comparative analysis (Fig. 2). It has been traced that persons with a positive perception of God show higher statistically significant points by the markers of spiritual and moral values, viz. self-development, spiritual needs, social contacts as well as pragmatic and egoistic values, in particular, financial standing, personal achievements, preservation of one's own individuality, as compared to those who consider God to be indifferent and strict.

Thus, believers, considering that God will support them at every moment more often strive for self-perfection, unlike those who stress the negative features in the image of God. People who imagine God as merciful and benevolent assume that their potential possibilities are unrestricted and that their full implementation will be achieved. They strive to preserve uniqueness and originality of their personality, views and lifestyle.

Also, believers who consider God to be an embodiment of the good and justice more frequently try to follow ethical norms in their conduct and activity. For them all aspects of human relations are of importance, they value the opinion of others as well as listening to pieces of advice given by others. People imagining God as merciful and benevolent consider that the most important thing in life is the possibility to communicate and interact with other people. They are characterized by sociability, empathy and social activity (they strive to help others, they participate in different events, etc.).

In spite of the aspiration to get moral satisfaction in all the spheres of life, believers who stress in the image of God care and omnipotence make the effort to achieve a high level of financial standing, considering it to be the main condition of their welfare. With that in view they choose the type of occupation which, in their opinion, ensures high level of income, and participate in the events presupposing some financial remuneration. 
Fig. 2. Figures of statistically significant means based on the results of a morphological test of life values for believers with different perceptions of God at $\mathrm{p}<0,05$; note: $S D$ - self-development, SN - spiritual needs, SC - social contacts, PA - personal achievements, FS - financial standing, PI - preservation of own individuality

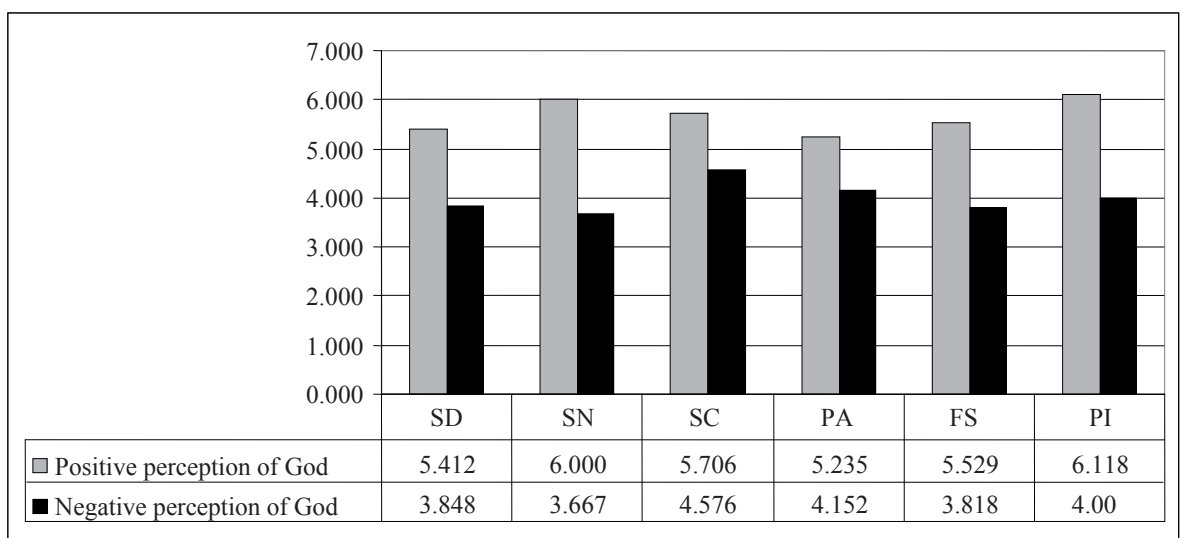

Source: Author.

People stressing in the image of God his permanence and invariability carefully plan their lives, set specific goals in each of its stages, striving to achieve them. For them the result of activity brings more satisfaction than the very process. Personal achievements in various spheres, in particular, professional, educational, family, become an important motivator in their further activity.

A man makes the effort to get information about the special features of his character that would point to the advantages of the individual over others. Considering God as a source of unrestricted love, man highly estimates his skills and abilities, he is of the opinion that he possesses unique and original skills unlike other people. Striving to find an explanation for the fact that in the worldview of believers for whom God is an embodiment of Christian virtues there dominate pragmatic and egoistic values, as compared to those considering God to be distant and indifferent one may assume the following. High financial standing, realization of personal achievements, preservation of one's individuality make a human confident of himself as well as fill him with comfort and safety since he has got the resources necessary to achieve the desirable ends. God, in the opinion of believers, does not obstruct, but, on the contrary, directs their activity and supports their initiatives, which, in their consideration, meet moral and ethical norms of conduct.

Unlike them, people imagining God as strict and indifferent to their lives, show points of lower significance by the markers of spiritual and moral as well as pragmatic and egoistic values (Fig. 2). The data obtained shows that believers who stress strictness and injustice in the image of God are not that frequently guided by such values as self-development, spiritual needs, social contacts, material provision, personal achievements as well as preservation of own individuality in their lives. 
People seeing God as gloomy and indifferent to their lives do not trust their own assessment, assuming that it is better to follow the advice of others. They rarely want to demonstrate their possibilities, since, in their opinion, human actions are not appreciated as they should be.

Considering that God has stopped taking care of their lives, believers show indifference to their personal achievements. In the event that the desirable is achieved, such people assign this success to an accidental concourse of circumstances. Human activity is primarily motivated by the goals for the immediate future, while those requiring a great loss of time and effort cause his passive awaiting position - "we'll see". In the opinion of such a person, one can achieve the desirable even without taking a great effort, since it is better to adjust to the circumstances than to strive to improve oneself.

Believers who consider God to be a strict and critical judge, more frequently than others ignore material welfare, considering it not to be a value that one should be guided by in one's life. They are of the opinion that there are other ideals, for instance, the one of the good and justice, towards which others should strive, in spite of the fact that in the outlook of the very believers they occupy the last places. Showing proneness to cynicism, to conflict and suspicion in relation to the people near and dear to them, individuals for whom God is an embodiment of despotism require from others respect for them. Such people consider themselves to be self-sufficient in all the spheres of life and activity and do not strive for excellence.

\section{CONCLUSIONS}

Nowadays it is more and more frequently the case that in mass media one may come across the statement that in Ukraine religion has come into fashion, while man, re-assessing spiritual values of the previous political regime, addresses religion and focuses on the values offered by church (http:/ / www.razumkov. org.ua/upload/prz_2011_Rlg_smll.pdf). Christian theologists, spiritual fathers and the clergy call believers to follow in their lives the values of mercy, love and justice that should become the leading and basic ones in human outlook. However, almost each second surveyed Christian is motivated to participate in religious activity not only by internal factors - striving for spiritual growth, - but by external factors as well, for instance, by social status support (Esip 2012, p. 126-133). In spite of the fact that for believers God is an embodiment of those Christian virtues, people strive to follow in their lives not only the values of spiritual and moral nature addressed by church or religious community, but also those of pragmatic and egoistic nature, due to which man achieves the desirable, preserves his individuality and is enriched financially. The change in sense and life orientations is traced with the appearance of a negative perception of God. Convincing themselves of injustice and strictness of God, believers re-assess their system of values they become indifferent and not confident as to what they strive to achieve in the future and what orientations, pragmatic and egoistic or spiritual and moral ones, shall be followed in life. 


\section{BIBLIOGRAPHY}

Allport G.W. (1998), Osobowość i religia, Instytut Wydawniczy PAX, Warszawa.

Esip M.Z. (2010), Апробаиія методики "Семантичний дифререниіал образу Бога" (СДОБ), (The adaрtаtion of the "semantic differential of the image of god" method), "Практична психологія та соціальна робота" 1 (130).

Esip M.Z. (2012), Психологічні особливості міжособових стосунків людей, схильних використовувати різні релігійні копінг-стратегіï (Psychological features of relations between people with tendencies to use various religious strategies of coping) "Психологічні перспективи: спеціальний випуск. Психологія професійної діяльності працівників соціальної сфери".

Maynard E.A., Gorsuch R.L., Bjorck J.P. (2001), Religious coping style, concept of God and personal variables in threat, loss and challenge situations, "Journal for the Scientific Study of Religion" 40.

Pargament K.I., Brant C.R. (1998), Religion and coping. Handbook of religion and mental health, Academic, New York.

Schaefer C.A., Gorsuch R.L. (1991), Psychological adjustment and religiousness: The multivariate belief-motivation theory of religiousness, "Journal of Scientific Study of Religion" 30 (4).

Современный словарь по психологии (Contemporary psychological vocabulary) (2000), Элайда, Минск.

Wong-McDonald A., Gorsuch R.L. (2000), Surrender to God: An additional coping style? "Journal of Psychology and Theology" 28.

Wulff D.M. (1999), Psychologia religii: Klasyczna i wspótczesna, WSiP, Warszawa.

\section{NETOGRAPHY}

Релігія і влада в Украйні: проблеми взаємовідносин. Інформаційно-аналітичні матеріали до Круглого столу “Державно-конфесійні відносини в Україні, їх особливості і тенденції розвитку" (Religion and power in Ukraine: The problems of relations. Informative-analytical materials of the "Church-state relations in Ukraine: their characteristics and tendencies of development" round table) (2011), http:/ /www. razumkov.org.ua/upload/prz_2011_Rlg_smll.pdf, retrieved: 23.10.2011.

Українщі стають однією із найрелігійніших нащиіи Європи (Ukrainians are becoming one of the most religious European nations), "Кореспондент" 29 квітня 2011 p., http://ua.korrespondent.net/ ukraine/1212519-korrespondent-ukrayinci-peretvoryuyutsya-v-odnu-iz-najreligijnishih-nacijevropi, retrieved: 04.11.2011. 